\title{
Anatomy, histochemistry and ultrastructure of seed and somatic embryo of Acrocomia aculeata (Arecaceae)
}

\author{
Elisa Ferreira Moura ${ }^{1}$; Marília Contin Ventrella $a^{2 *}$; Sérgio Yoshimitsu Motoike ${ }^{1}$ \\ ${ }^{1} U F V$ - Depto. de Fitotecria, Lab. de Cultura de Tecidos e Células Vegetais. \\ ${ }^{2} U F V$ - Depto. de Biologia Vegetal, Lab. de Anatomia Vegetal, Av. P.H. Rolfs, s/n-36570-000 - Viçosa, MG - \\ Brasil. \\ *Corresponding author < ventrella@ufv.br>
}

\begin{abstract}
Macaw palm (Acrocomia aculeata (Jacq.) Lodd. ex Mart.) is a tropical species with multiple uses, including oil supply for biodiesel production. However, structural and physiological studies of the seed are still scarce, as well as in vitro propagation techniques. The aim of this study was to characterize the anatomy, histochemistry and ultrastructure of the seed and the in vitro somatic embryo of $A$. aculeata, gaining insight into relationships between the post-harvest seed behavior and the somatic embryo conversion to plant. The zygotic embryo and the endosperm show high quantities of protein and lipids, stored in protein and lipid bodies, respectively. The cell wall storage polysaccharides occur in the thickened cell wall of the endosperm. The absence of vacuoles and the few organelles, except for the storage ones, indicate low metabolic state of the zygotic embryo, which suggests a orthodox behavior of the seed at maturity. The somatic embryo shows a shoot meristem with few leaf primordia, vacuolated cells and, occasionally, amyloplasts, but not lipid or protein reserves. These characteristics, common in somatic embryogenesis, could be associated with the maturation phase, and, consequently, with the low conversion of these embryos into plants.
\end{abstract}

Key words: macaw palm, zygotic embryo, endosperm, storage reserves

\section{Anatomia, histoquímica e ultra-estrutura da semente e do embrião somático de Acrocomia aculeata (Arecaceae)}

\begin{abstract}
RESUMO: A macaúba (Acrocomia aculeata (Jacq.) Lodd. ex Mart.) é uma espécie tropical com múltiplos usos, incluindo a geração de óleo para a produção de biodiesel. Entretanto, estudos estruturais e fisiológicos da semente ainda são escassos, assim como as técnicas de propagação in vitro. Caracterizaram-se a anatomia, a histoquímica e ultraestrutura da semente e do embrião somático de $A$. aculeata obtido in vitro, visando a obter relações entre o comportamento pós-colheita da semente e a conversão em planta a partir do embrião somático. O embrião zigótico e o endosperma apresentam alta quantidade de proteínas e lipídios, estocados em corpos protéicos e lipídicos, respectivamente. Os polissacarídeos de reserva da parede celular estão presentes nas paredes celulares espessadas do endosperma. A ausência de vacúolos e as poucas organelas visualizadas, exceto as organelas de reserva, indicam baixo estado metabólico do embrião zigótico, o que sugere comportamento ortodoxo da semente madura. O embrião somático apresenta meristema apical com poucos primórdios foliares, células com vacúolos conspícuos e, ocasionalmente, amiloplastos, mas não há reservas protéicas ou lipídicas. Essas características, comuns na embriogênese somática, podem estar associadas à fase de maturação dos embriões e, consequentemente, com a baixa conversão desses embriões em plantas.
\end{abstract}

Palavras-chave: macaúba, embrião zigótico, endosperma, substâncias de reserva

\section{Introduction}

Macaw palm (Acrocomia aculeata) is a monoecious member of Arecaceae family with great dispersion in America and very common in areas of the Brazilian Cerrado. Among oleaginous plants, macaw palm is the second most productive (1500 to $5000 \mathrm{~kg}$ oil ha ${ }^{-1}$ ), inferior only to oil palm (Elaeis guineensis). Besides the high productivity achieved after four years of growth, $A$. aculeata can produce for over 100 years, and that gives this species a great potential for biodiesel production.

Data about the structure of $A$. aculeata seed and its technological characteristics are still scarce, especially those referring to anatomical, histochemical and ultrastructural aspects. Propagation is usually carried out through seeds, but the development and improvement of in vitro propagation techniques are necessary to speed up and facilitate genetic breeding programs. Somatic embryos in vitro were recently obtained (Moura et al., 2008, 2009), but the rate of plantlets conversion is still low.

Light and transmission electron microscopy techniques have been used as tools to characterize palm seeds (Aguiar and Mendonça, 2003; Panza et al., 2004), storage reserves (Alang et al., 1988; De Mason et al., 1983), embryos (DeMason, 1988) and also to evaluate the development of somatic embryos in vitro (Aberlenc-Bertossi et al., 1999; Duval et al., 1995; Kanchanapoom and Domyoas, 1999; Rajesh et al., 2003; Schwendiman et al., 1988; Tisserat and De Mason, 1980; Verdeil et al., 1994). 
The objective of this study was to characterize the anatomy, histochemistry and ultrastructure of $A$. aculeata seed and somatic embryos obtained in vitro, aiming to establish connections between the seed postharvest behavior and the establishment of plants from somatic embryos.

\section{Material and Methods}

\section{Material source}

The seeds were obtained from mature fruits of $A$. aculeata plants from the West Region of the state of Minas Gerais, Brazil (16⒉ $21^{\prime}$ S, $44^{\circ} 12^{\prime}$ W). The endocarp and mesocarp were manually removed and the endocarp was creaked using a bar clamp to obtain the seeds. Indirect somatic embryos were obtained from zygotic embryos. The embryogenic callus was started in Petri dishes on a medium composed of Y3 salts (Eeuwens, 1978), $68.46 \mathrm{~g} \mathrm{~L}^{-1}$ sucrose, $1.0 \mathrm{~g} \mathrm{~L}^{-1}$ hydrolyzed casein, $100 \mathrm{~g} \mathrm{~L}^{-1}$ myo-inositol, $9 \mu \mathrm{M}$ picloram, and solidified with $2.5 \mathrm{~g}$ $\mathrm{L}^{-1}$ gelrite (Moura et al., 2009). After 60 days of induction in the dark, at $25 \pm 2{ }^{\circ} \mathrm{C}$, the somatic embryogenic callus formed was subcultured for another 60 days in the same medium supplemented with $3 \mathrm{~g} \mathrm{~L}^{-1}$ active charcoal to generate somatic embryos (Moura et al., 2009). The somatic embryos were germinated in the medium above but deprived of picloram.

\section{Light microscopy (LM)}

Seed coat, endosperm and zygotic embryo, fresh or fixed for 48 hours in $\mathrm{FAE}_{50}$ (formalin: acetic acid: 50\% ethyl alcohol, 5:5:90, v/v/v) and stored in 70\% ethanol (Johansen, 1940), were transversally sectioned in a tablemicrotome (LPC Rolemberg \& Bhering). The histochemical tests used were: periodic acid-Schiff reagent (PAS) stain (Feder and O'Brien, 1968) for polysaccharides with vicinal glycol groups, iodine zinc chloride (Johansen, 1940) and calcofluor white MR2 (Hughes and McCully, 1975) for cellulosic polysaccharides, Ruthenium red (Johansen, 1940) and coriphosphine (Ueda and Yoshioka, 1976) for pectins, Lugol's iodine solution (Johansen, 1940) for starch, xylidine Ponceau (Vidal, 1977) for proteins, Sudan black B (Johansen, 1940) for lipids, Nile blue sulphate (Cain, 1947) for acid and neutral lipids, osmium tetroxide (Ganter and Jollés, 1969) for unsaturated lipids, ferric trichloride (Johansen, 1940) for phenolic compounds and phloroglucin (Johansen, 1940) for lignin.

Portions of $0.25 \mathrm{~cm}^{2}$ of seed coat, endosperm, zygotic and somatic embryos were embedded in methacrylate (Leica Historesin), according to the manufacturer's recommendations and were transversally and longitudinally sectioned in a rotate microtome (Spencer 820), with $5 \mu \mathrm{m}$ thickness. Toluidine blue O (O'Brien et al., 1964) was used for metachromasy and as a counter-staining to Lugol for starch detection. Standard control procedures were carried out simultaneously. Polarized light was used for detection of anisotropic substances. Histochemical tests applied in a fresh material were also performed in embedded material. The images were obtained using Olympus (AX-70) light microscope, equipped with photographic system U-photo, and the Spot-Basic software. Fluorochromes (coriphosphine and calcofluor white) and autofluorescence investigation were used in an epifluorescence system equipped with a UV filter (WU: 330-385 nm), a dichroic mirror $(400 \mathrm{~nm})$ and a barrier filter $(420 \mathrm{~nm})$.

\section{Transmission electron microscopy (TEM)}

One $\mathrm{mm}^{2}$ portions of endosperm, zygotic and somatic embryos were fixed with $2.5 \%$ glutaraldehyde in $0.1 \mathrm{M}$ sodium phosphate buffer, $\mathrm{pH} 7.2$, for $4 \mathrm{~h}$, at room temperature, and rinsed in the same buffer six times for $10 \mathrm{~min}$. The material was postfixed in $1 \%$ sodium phosphate buffered osmium tetroxide $\left(\mathrm{OsO}_{4}\right)$ for $4 \mathrm{~h}$, at $4^{\circ} \mathrm{C}$, and rinsed in the same buffer six times for $10 \mathrm{~min}$. After dehydration in a graded ethanol series, the material was embedded in Spurr's epoxy resin. Ultrathin sections were cut at a thickness of 60 to $90 \mathrm{~nm}$ on a MT2-B ultramicrotome (Du Pont-Sorval) with a diamond knife. Sections were collected on Formvar-coated copper grids and conventionally stained with uranyl acetate and lead citrate. Specimens were observed with a Zeiss EM 109 transmission electron microscope operating at $80 \mathrm{kV}$.

\section{Results}

The seed of $A$. aculeata is heart-shaped to triangleshaped in a longitudinal section, has a dark and thin seed coat (Figure 1A-C), is filled by the abundant endosperm and a diminutive embryo (Figure 1C-D), and has an empty and small central cavity. The seed coat is smooth, thin and composed by approximately 20 layers of isodiametric no living cells, which have thin and non-lignified walls (Figure 2A). The brown color of the seed coat (Figure 1) is generated by an orange substance present in its lumen cells, a phenolic compound revealed by the ferric trichloride test (not shown) and by the green to yellow color with toluidine blue (Figure 2A). The lack of mechanical resistance of the seed coat may be associated with the presence of the sclerified endocarp, which guarantees mechanical protection to the seed.

\section{Endosperm}

The endosperm of $A$. aculeata seed is plentiful, whitish, and relatively hard and oily (Figure 1C). The cells are isodiametric and polygonal in paradermal sections (Figure 2G-I). They are more extended in transversal sections (Figure 2B-F), with thick and electron-dense walls (Figure 3A-B) that constitute insoluble carbohydrates reserves, as shown by the PAS test (Figure 2B). Cell walls are non-cellulosic and non-lignified, as confirmed by tests with iodine zinc chloride and chloridic vaniline, respectively. The chemical composition of the cell walls, however, seems not to be uniform, and the inner cell wall colored more intense, as shown by the toluidine blue (Figure $2 \mathrm{C})$. The ruthenium red test shows that the inner cell wall layer is rich in pectins, with a strong rose color (Figure $2 \mathrm{D}$ ). The same is shown by the coriphosphine test, a 


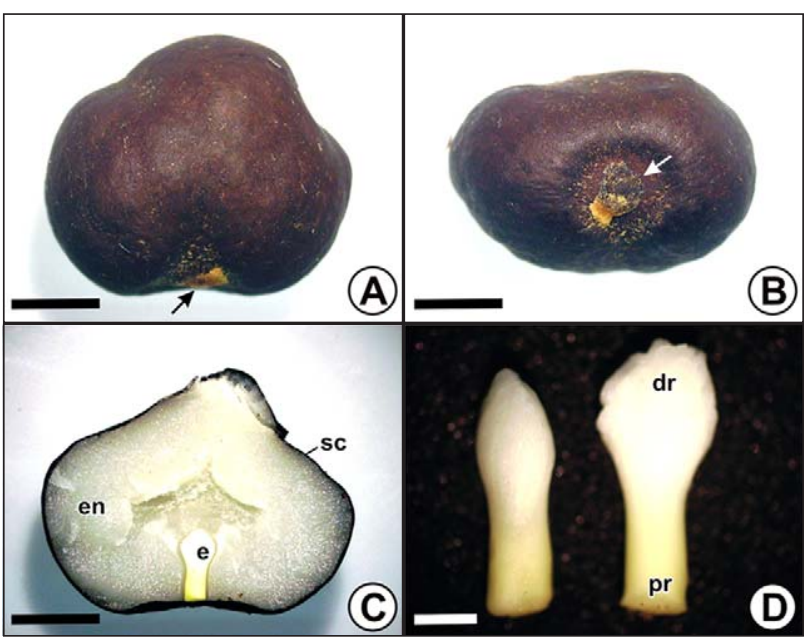

Figure 1 - Acrocomia aculeata seeds (A-C) and embryos (D). A-B: Hole seeds in longitudinal (A) and transversal (B) view (bars $=5 \mathrm{~mm}$ ). Arrows indicate the embryo position in the seed. C: General aspect of de seed sectioned longitudinally (bar $=5 \mathrm{~mm}$ ). D: Two embryos separated from the seed (bar $=1 \mathrm{~mm})$. E, embryo; en, endosperm; dr, distal region; pr, proximal region; sc, seed coat.

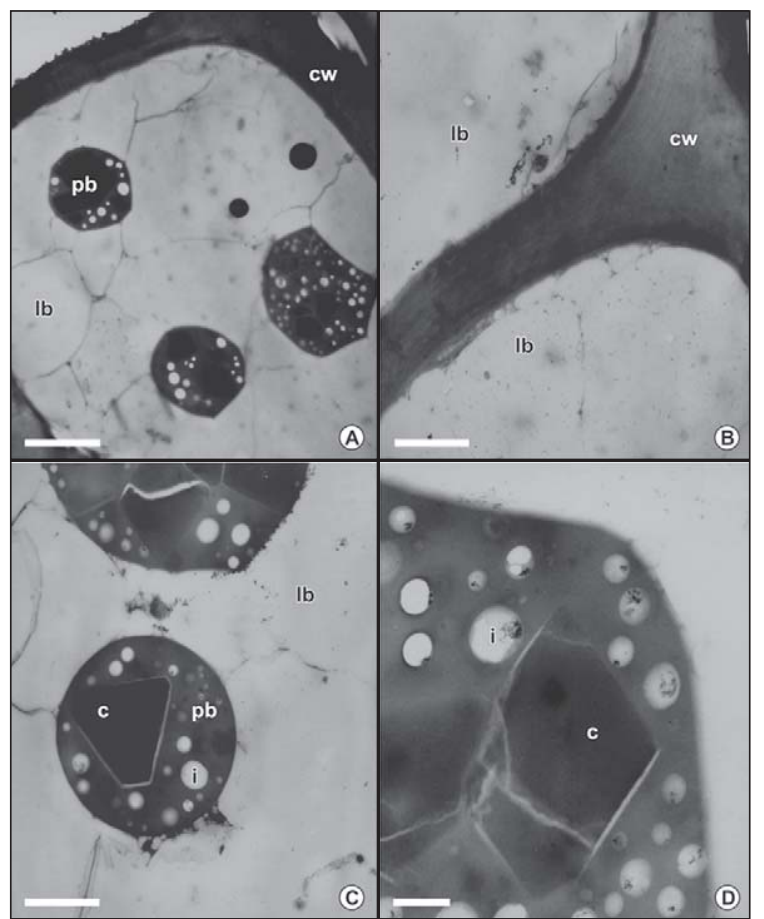

Figure 3 - Transmission electron micrographs of Acrocomia aculeata endosperm. A: General aspect of an endosperm cell with protein and lipid bodies (bar = $5 \mu \mathrm{m})$. B: Detail of the cell wall and of coalesced lipid bodies (bar $=2 \mu \mathrm{m})$. C: Protein bodies with numerous inclusions globoid crystals and protein crystalloids (bar $=2 \mu \mathrm{m})$. D: Detail of a protein body (bar $=0.5 \mu \mathrm{m})$. In A, C and D, globoid crystals are indicated in empty areas that contained globoid crystals before they chipped out during sectioning. $\mathrm{Cw}$, cell wall; lb, lipid body; i, inclusions; $\mathrm{pb}$, protein body; pc, protein crystalloid.

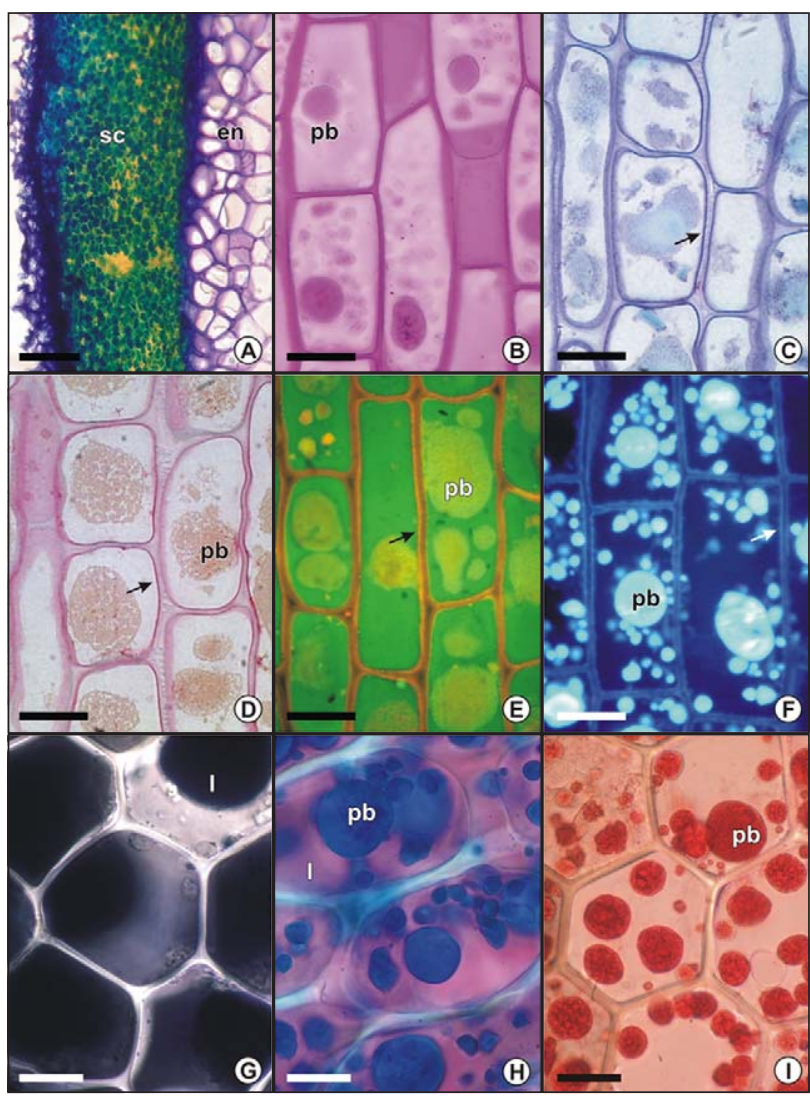

Figure 2 - Light micrographs of Acrocomia aculeata seed coat (A) and endosperm (B-I) submitted to different histochemical tests. A, G-I: Fresh sections. B-F: Metacrylate embedded sections. A: Seed coat and adjacent endosperm coloured with toluidine blue; positive reaction for phenolic coumpounds gives a green color $($ bar $=50 \mu \mathrm{m})$. B: PAS for polysacchaderides; positive reaction shows magenta color $($ bar $=50 \mu \mathrm{m})$. C: Toluidine blue for metacromasy (bar $=50 \mu \mathrm{m})$. D: Ruthenium red for pectins; positive reaction shows rose color $(\mathrm{bar}=50$ $\mu \mathrm{m})$. E: Coriphosphine for pectins; positive reaction shows orange secondary fluorescence (bar $=50 \mu \mathrm{m})$. F: Calcofluor white for cellulosic polysaccharides; positive reaction shows pale blue secondary fluorescence $(\mathrm{bar}=50 \mu \mathrm{m})$. In C-F, arrows show the inner wall layer differentially stained. G: Sudan black $\mathrm{B}$ for lipids; positive reaction gives a dark blue color (bar $=25 \mu \mathrm{m})$. H: Nile blue for neutral lipids; positive reaction shows pink color (bar $=25 \mu \mathrm{m})$. I: Xylidine Ponceau for proteins; positive reaction shows red color (bar $=25 \mu \mathrm{m})$. En, endosperm, 1, lipid; pb, protein body; sc, seed coat.

fluorochrome that indicates the pectin presence in the inner cell wall layer by a secondary orange fluorescence (Figure 2E). Calcofluor white, which is used for $\beta-(1 \rightarrow 4)(1 \rightarrow 3) \mathrm{D}$ glucans detection, also shows that the inner cell wall layer, with the more intense pale blue fluorescence, differs in composition in comparison to the outer cell wall layer (Figure 2F). The middle lamella is weakly stained by all tests applied for pectins. 
The presence of lipids is confirmed by Sudan black B (Figure 2G) and osmium tetroxide tests, which reacts positively for lipids. Nile blue test (Figure $2 \mathrm{H}$ ) confirms the presence of neutral lipids, as triacylglycerols, which are colored in pink. The lipids are stored in the form of lipid bodies (Figure 3). Protein bodies are stained positively by PAS (Figure 2B) and by the xilidine Ponceau test, which stains the protein bodies in red (Figure 2I). The protein bodies are large and spherical, with an electron-dense proteinaceous matrix and numerous inclusions of globoid type (small and rounded) and protein crystalloids (big, prismatic and more electron-dense than the protein matrix) (Figure 3A, C-D). The lipid and protein bodies occupy together, a great proportion of the total endosperm cell lumen. The nucleus is prominent in the endosperm cells, but only a few organelles are visualized besides lipid and protein bodies. The accumulation of lipid and protein bodies is uniform in all regions of the endosperm.

The embryo of $A$. aculeata is key shaped, whitish and has approximately $4 \mathrm{~mm}$ in length (Figures 1C-D, 4A). The proximal region (Figure 1D, 4A, D), connected with the seed coat, is narrower than the distal region and has yellow color. The distal region, connected with the endosperm, is more dilated and clearer than the proximal region (Figure 1D, 4A-B). The shoot apical meristem is covered by two or three leaf primordia, curved and obliquely angled with respect to the cotyledon axis, on the proximal region (Figure 4A, D, F). The distal region (Figure 4A-B) is composed entirely of the highly developed cotyledon and there are many invaginations in the region connected to the endosperm which gives it a ruminate aspect (Figure 4E). Protodermis, ground meristem and procambial strands can be identified in all embryogenic structure by their cells shape, size and position (Figure 4). Procambial cells are long, narrow and intensely stained by the toluidine blue $\mathrm{O}$. The procambial strands is closely related to the leaf primordia in the proximal region (Figure 4D), and ramify in the median region (Figure $4 \mathrm{C}$ ) toward the distal region (Figure 4B), becoming peripheral, closer to the protodermis. Ground meristem cells are isodiametric, and are bigger on the medular than in the cortical cotyledon region. Protodermis cells are tabular in outline, prominent in the distal region and they form a distinct layer that covers the entire embryo.

The zygotic embryo cell walls are thinner than endosperm cell walls (Figure 5A-D). The nucleus is conspicuous and the largest portion of the cytoplasm is occupied by lipids (Figures 4G- I), and proteins, (Figure $4 \mathrm{~J}$ ), which are stored in lipid (Figure 5A-C) and protein bodies (Figure 5A-B), respectively. Lipids are identified by tests with Sudan black B (Figure $4 \mathrm{G}$ ), osmium tetroxide (Figure 4H) and Nile blue (Figure 4I), but apparently in smaller amounts than in the endosperm. The lipid bodies are small and fill the entire cytoplasm portion that is not occupied by other organelles (Figure 5A-C). The protein bodies are stained in red with xylidine Ponceau (Figure 4J), and are proportionally more abun- dant in the zygotic embryo than in the endosperm; they only have globoids distributed in the proteinaceous matrix (Figure 5A-B). There are no starch grains identified by the PAS test or lugol reagent. In general, the composition of the zygotic embryo storage reserves is very similar to the endosperm, except for the stored polysaccharides of the cell wall, which are scarcer (Figure 5AB). The storage substances occur in all regions of the zygotic embryo, mainly in the protodermal and ground meristem cells.

The somatic embryo has rounded or long shape, with cream color (Figure 6A-B). The separation between the distal and proximal regions is not evident, as occurs in the zygotic embryo. Protodermis, ground meristem and procambium, are clearly identified. The shoot meristem is also present, but there is only one leaf primordium (Figure 6C) and in the zygotic embryo there are two or three well developed leaf primordium. Cell walls are also thinner than in the zygotic embryo, but have some regions of irregular thickening (Figures 6D-E, 7A-B). The nuclei are prominent, and, occasionally, contain more than one nucleolus (Figures 6D, 7A). Cytoplasm is abundant, partially electron-dense, and has many and large vacuoles, which occupy a considerable portion of the cytoplasm (Figure 7A). In some cells, the vacuoles present granular regions with electron-dense material, alternating with clearer areas (Figure 7B). There are no lipids or protein as storage material. There are rounded and membrane-delimited structures or vesicles, with small amount of granular material in their interior (Figure $7 \mathrm{~B})$, either in vacuole or in the region next to the plasma membrane. Also, in several points, these vesicles coalesce with the plasma membrane, in a process similar to an exocytosis (Figure 7C-D). Occasionally, amyloplasts were present and identified by lugol reagent (Figures 6E, 7E-F), however, they are not abundant or uniformly distributed all over the somatic embryo cells.

\section{Discussion}

The seed coat of $A$. aculeata is mechanically fragile because the isodiametric cells of thin and non-lignified walls, do not confer mechanical protection, which is guaranteed by the hard sclerenchymatous and lignified endocarp as in Cocos nucifera (Roth, 1977). The endosperm of $A$. aculeata has characteristics of other species of palms, since it is abundant and hardened, rich in lipids, proteins and cell wall storage polysaccharides (Alang et al., 1988; Aguiar and Mendonça, 2003; DeMason et al., 1983; DeMason, 1988; Panza et al., 2004). These lipids found in palm seeds are insaturated lipids used in biodiesel process and the levels of such lipids could be genetically improved in breeding programmes selecting elite plants by somatic embryogenesis.

In palm seeds, the endosperm cell wall is generally thicker because of the deposition of cell wall storage polysaccharides, mainly the hemicelluloses mannan (Buckeridge et al., 2000). In $A$. aculeata the endosperm cell walls are not very thick, and the primary pit fields 

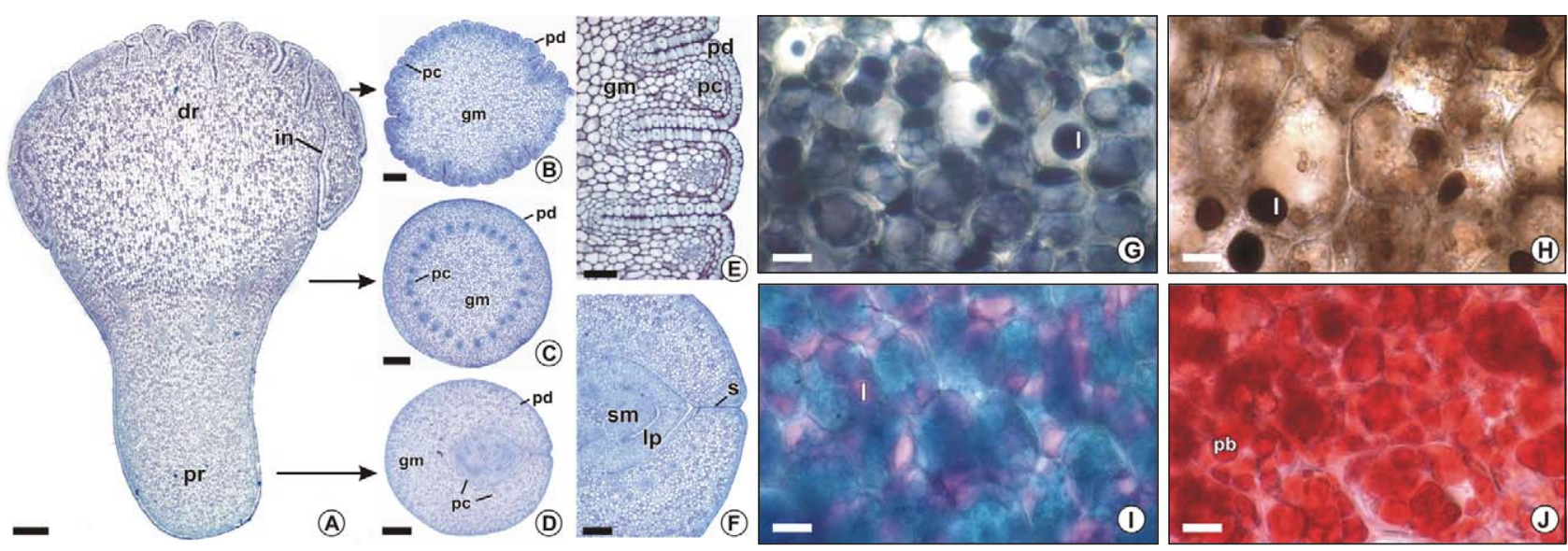

Figure 4 - Light micrographs of zygotic embryo of Acrocomia aculeata stained with toluidine blue (A-F) and submitted to different histochemical tests (G-J). A-F: Metacrylate embedded sections. G-J: Fresh sections. A: Longitudinal section of the zygotic embryo $($ bar $=250 \mu \mathrm{m})$, arrows indicate positions of transversal sections in B, C and D. B: Distal region $($ bar $=250 \mu \mathrm{m})$. C: Median region $(\mathrm{bar}=300 \mu \mathrm{m})$. D: Proximal region $(\mathrm{bar}=300 \mu \mathrm{m})$. E: Detail of the distal region, on transversal section, with the invaginations of the cotyledon $(\mathrm{bar}=70 \mu \mathrm{m})$. F: Detail of the proximal region, on transversal section, with the shoot meristem (bar $=150 \mu \mathrm{m})$. G-J: Transversal sections (bar $=15 \mu \mathrm{m})$. G: Sudan black B for lipids, positive reaction shows dark blue color. H: Osmium tetroxide for lipids, positive reaction shows brown color. I: Nile blue for neutral lipids, positive reaction shows pink color. J: Xylidine Ponceau for proteins, positive reaction shows red color. Dr: distal region; gm: ground meristem; in, invagination; 1: lipid; lp: leaf primordia; pb: protein body; pc: procambial strand; pd: protodermis; pr: proximal region; s: slit; sm: shoot meristem.

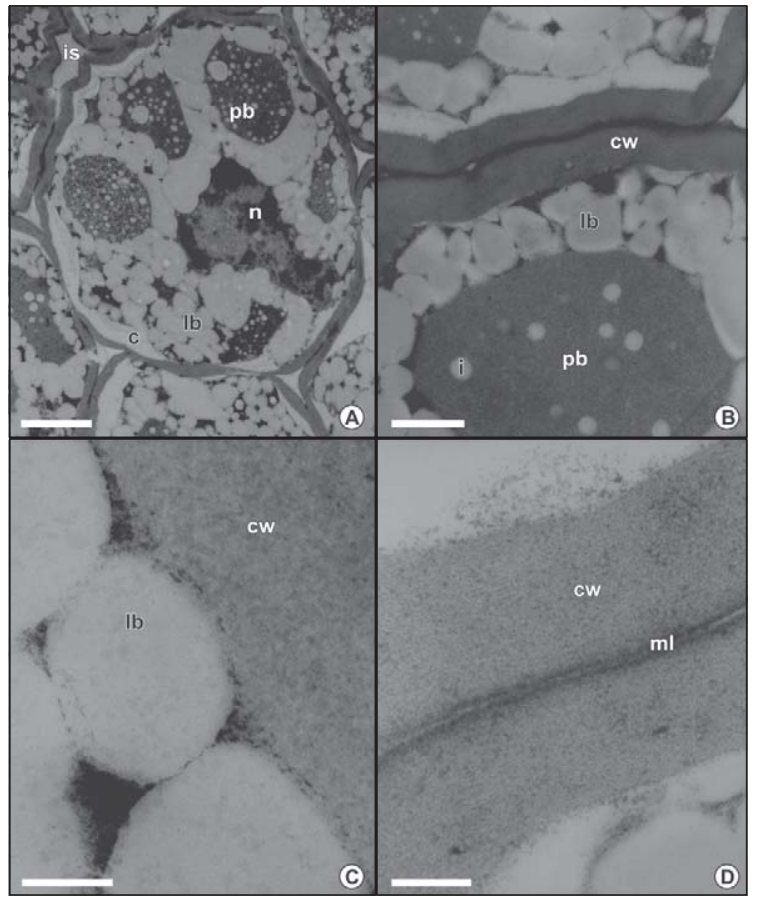

Figure 5 - Transmission electron micrographs of Acrocomia aculeata zygotic embryo. A: General aspect of ground meristem cells (bar $=3 \mu \mathrm{m})$. B: Detail of the cell wall, lipid bodies and protein bodies with spherical inclusions of two adjacent cells (bar $=1$ $\mu \mathrm{m})$. C: Detail of lipid bodies (bar $=0.2 \mu \mathrm{m})$. D: Detail of the cell wall of two adjacent cells with electron-dense middle lamella (bar $=0.3 \mu \mathrm{m})$. C, citoplasm; cw, cell wall; i, inclusion; is, intercellular space; lb, lipid body; ml, middle lamella; n, nucleus; $\mathrm{pb}$, protein body.

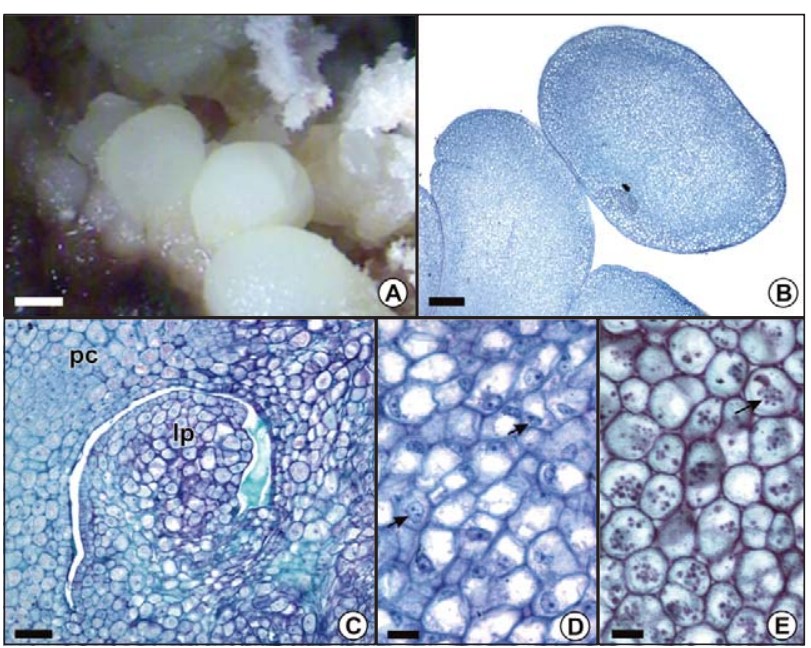

Figure 6 - Somatic embryos of Acrocomia aculeata. A: In vivo somatic embryo (bar $=1 \mathrm{~mm})$. B-E: Light micrographs of metacrylate embedded sections stained with toluidine blue (B-D) or with toluidine blue and lugol (E). B: Detail of somatic embryos emerging from budding (bar $=200 \mu \mathrm{m})$. C: Section of the shoot meristem and leaf primordia of somatic embryo $($ bar $=50 \mu \mathrm{m})$. D-E: Transversal sections (bar $=15 \mu \mathrm{m})$. D: Detail of somatic embryo cells, arrows indicate cells with nuclei and more than one nucleolus. E: Staining with toluidine blue and lugol indicates starch grains (arrows). Lp: leaf primordia; pc: procambial strand. 


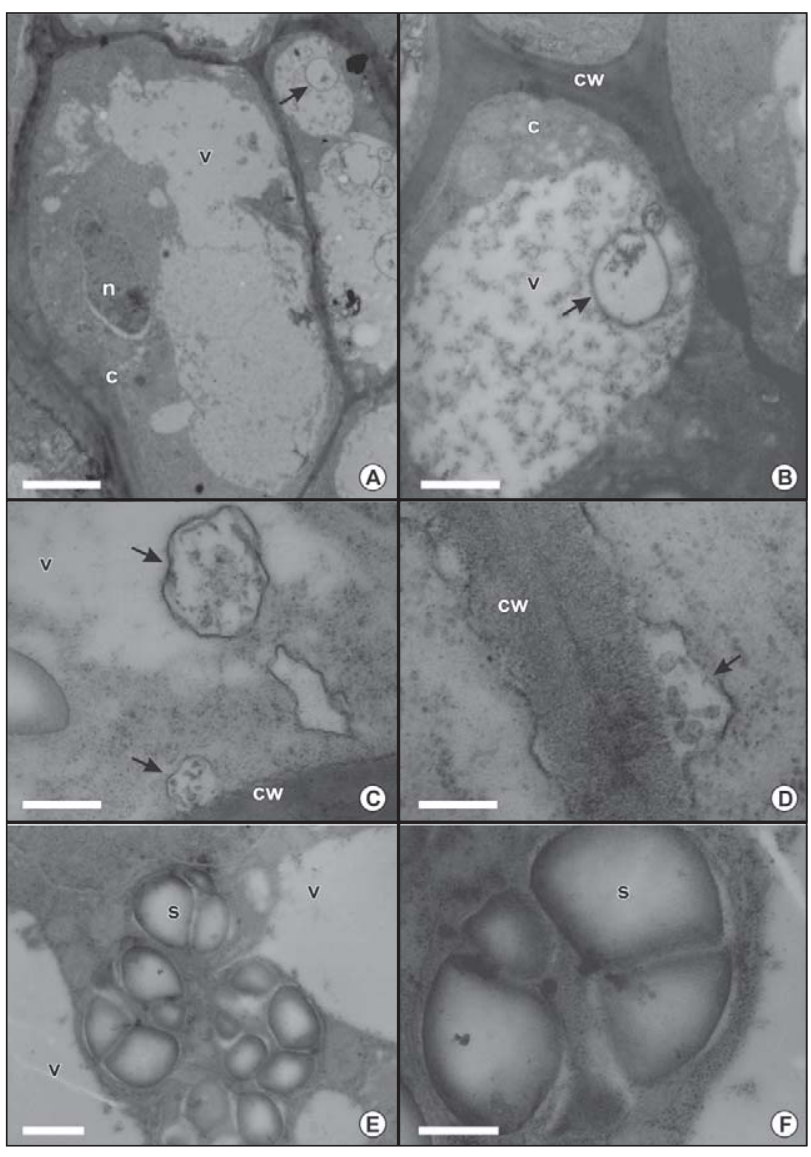

Figure 7 - Transmission electron micrographs of Acrocomia aculeata somatic embryo from in vitro culture. A: General aspect of vacuolated ground meristem cells with no apparent storage material (bar $=3 \mu \mathrm{m})$. B: Vacuole presents electron-dense granular content and vesicular structures (arrow) surrounded by membrane and electron-dense content (bar $=1 \mu \mathrm{m})$. C-D: Vesicular structures (arrows) starting to fuse with the plasma membrane $(C$, bar $=0.5 \mu \mathrm{m} ; \mathrm{D}$, bar $=0.2 \mu \mathrm{m})$. E-F: Amyloplasts with several starch grains $(\mathrm{E}$, bar $=1 \mu \mathrm{m} ; \mathrm{F}$, bar $=0.5 \mu \mathrm{m})$. C: cytoplasm; cw: cell wall; $\mathrm{n}$ : nucleus; s: starch grain; $\mathrm{v}$, vacuole.

are inconspicuous. Therefore, three layers were differentiated in endosperm cell walls of some palms, as in Phoenix dactylifera (DeMason et al., 1983), Washingtonia filifera (DeMason, 1986) and Euterpe edulis (Panza et al., 2004). These layers, the middle lamella and the outer and inner walls, are also present in the endosperm cell walls of $A$. aculeata. In this species, pectins present in the middle lamella and especially in the inner cell wall layer could be recognized in a small amount.

Thus, the mannan hemicelluloses dominate the composition of $A$. aculeate endosperm cell walls. "Pure mannans", or polysaccharides which contain less than $10 \%$ of nonmannose sugar residues, are the major polysaccharide extracted from the mature endosperm of all palm species studied (Meier and Reid, 1982). Mannans compound the endosperm cell walls of the date palm (Phoenix dactylifera) and ivory nut palm (Phytelephas macrocarpa
(Meier, 1958; Meier and Reid, 1982). Mannans function as storage polysaccharides after germination and are also related to endosperm stiffness and control of the radicle protrusion (Alang et al., 1988; Buckeridge et al., 2000).

The cell wall storage polysaccharides of the endosperm represent storage for the post-germinative period (Buckeridge et al., 2000), but lipids and proteins found in the endosperm and zygotic embryo are reserves consumed in the initial stages of germination and plantlet establishment (Bewley and Black, 1983). However, in the palm Elaeis guineensis the insoluble polysaccharides are degraded and utilized more rapidly than lipid during the early stages of germination (Alang et al., 1988). The triacylglicerols constitute the main class of lipids in seeds and they are stored in the lipid bodies (Ferreira and Borguetti, 2004), as verified in other species of Arecaceae (DeMason and Thomson, 1981; DeMason et al., 1983; Panza et al., 2004). In A. aculeata, the lipid bodies are abundant in the endosperm and zygotic embryo cells, and triacylglycerol are rich in saturated fatty acids, especially lauric acid (Hiane et al., 2005). The lipid bodies are much expanded in the endosperm, as if they had partially adhered, which certainly were an artifact during processing. In Euterpe edulis (Panza et al., 2004), as in A. aculeate, mature seeds are analyzed, and the lipid bodies are similar. In palms such as Washingtonia filifera (DeMason, 1986) and Phoenix dactylifera (DeMason et al., 1983), the seeds were soaked in water for several days before fixation, and the lipid bodies were smaller, rounded and were not coalesced, however, the germinative process was initiated.

The protein bodies of $A$. aculeata endosperm show globoid crystals and one or more protein crystalloids in the proteinaceous matrix. The zygotic embryo only has globoids spread in the proteinaceous matrix, which constitute mineral reserve, especially phytin (Lott, 1981). The ultrastructural differentiation of protein bodies also occurs in the seeds of Washingtonia filifera (DeMason, 1986, 1988). In the embryos, protein bodies are smaller and contain only globoids, and in the endosperm, they are bigger, with globoids and also protein crystalloids included in the proteinaceous matrix (DeMason, 1986, 1988). In Euterpe edulis (Panza et al., 2004), where there are no protein and lipid reserves in the embryo, but only in the endosperm, the protein bodies are similar to the ones found in the endosperm of $A$. aculeata. There were several embryo- and endosperm-specific proteins in Phoenix dactylifera; and the latter are consistent with the hypothesis that the endosperm is a possible source of hydrolytic enzymes during germination and seedling development (Sekhar and DeMason, 1988).

Besides the conspicuous and corpulent nucleus, few organelles can be visualized in the endosperm cells, in addition to those related to lipid and protein accumulation. This may suggest low metabolic activity and endosperm function more restricted to storage, as verified in the endosperm of Phoenix dactylifera (DeMason et al., 1983) and Washingtonia filifera (DeMason, 1986). 
Considering the morphology, the zygotic embryo is similar to most embryos of the Arecaceae family and has a single corpulent cotyledon and a short radicle hypocotyl axis and an epicotyl (Aguiar and Mendonça, 2003; Kanchanapoom and Domyoas, 1999; Panza et al., 2004; Steinmacher et al., 2007). The apical meristem covered by the leaf primordia is obliquely angled with respect to the cotyledon axis, as in the embryos of Elaeis (Kanchanapoom and Domyoas, 1999), Phoenix (DeMason and Thomson, 1981) and Washingtonia (DeMason, 1988). A particular character of $A$. aculeata zygotic embryo, not yet verified in other palm embryos, is the ruminate aspect of the cotyledon, generated by invaginations of the protodermis and subjacent tissues. These invaginations may be associated with a higher efficiency in material transport from the endosperm to the embryo. The distal portion of the palm cotyledon remains inside the seed after germination, expands in size and functions as a haustorium, which absorbs and replaces the endosperm (Tomlinson, 1960). This haustorium is typical of the palm embryos (Arecaceae family), and participates in the hydrolysis of lipid, protein and carbohydrate reserves, and in the mobilization of nutrients to the emerging plantlet (Verdeil and Hocher, 2002).

The level of differentiation of the protodermis, ground meristem and procambium is common in other Arecaceae species (DeMason and Thomson, 1981; DeMason, 1988). The great proportion of lipid and protein reserves in the embryo and in the endosperm is also common in seeds of the Arecaceae family, as in Washingtonia filifera (DeMason, 1986; 1988) and Phoenix dactylifera (DeMason and Thomson, 1981; DeMason et al., 1983). An extreme case is seen in the seed of Euterpe edulis, where the endosperm, but not the embryo, accumulates reserves (Panza et al., 2004). In this species, the embryo has high water content, does not have storage material and shows an active state, with numerous vacuoles, mitochondria, RER cisterns and dyctyosomes in its cells, which highlights the strategy of continuous development (Panza et al., 2004). The high water content at maturity and the presence of big vacuoles in the embryonary cells are characteristics of recalcitrant seeds, which suffer irreversible damages during desiccation or prolonged storage (Pammenter and Berjak, 1999).

The $A$. aculeata seed has a large amount of reserves in the embryo and in the endosperm, and presents a few organelles related to metabolic activity, which suggests that the species is orthodox, considering its structure. The $A$. aculeata seed moisture content is relatively low, with $9.13 \%$ in the embryo and $5.52 \%$ in the endosperm (Motoike, unpublished data). These values also suggest that it is a orthodox seed. Nevertheless, studies about storage periods and conditions might be conducted to better understand the physiology of this seed. Tropical species tend to be sensitive to low temperatures or to long periods of storage, even with a low water content, and they are considered to have an intermediary postharvest behavior (Pammenter and Berjak, 1999).
The somatic embryo of Arecaceae, unlike zygotic embryos does not accumulate proteins and lipids (Kanchanapoom and Domyoas, 1999; Schwendiman et al., 1988; Sané et al., 2006; Sghaier et al., 2008). There are some differences between the zygotic and the somatic embryo of $A$. aculeate; the last one shows a higher number of vacuolated cells, no lipids and proteins reserves, and has scarce amyloplasts. In somatic embryos of Elaeis guineensis, protease activity was present throughout embryogenesis and germinative growth, and likely explains the low accumulation of storage proteins in these embryos compared to the zygotic ones (Aberlenc-Bertossi et al., 2008). In some species, starch is transient in the seeds, and may be present during the formation of the endosperm and the zygotic embryo, as a temporary form of reserve (Otegui et al., 1998). In the embryogenic cells of Cocos nucifera (Verdeil et al., 2001) and Elaeis guineensis (Kanchanapoom and Domyoas, 1999; Schwendiman et al., 1988), the storage of starch grains during the embryogenesis is commonly observed.

Somatic embryos of Tilia cordata also had vacuolated cells and low reserve material when the maturation phase was suppressed, while embryos submitted to maturation treatments become very similar to the zygotic embryos (Karkonen, 2000). Generally, the conversion of $A$. aculeata somatic embryos into plantlets was low (Moura et al., 2009), and treatments that lead to embryo maturation are still necessary to improve the germination process. Fki et al. (2003) demonstrated that partial desiccation of the mature somatic embryos of Phoenix dactylifera and the cutting back of the cotyledonary leaf were also found to stimulate embryo germination. Somatic embryos of Elaeis guineensis have low regeneration rates and histological observations show that shoot development might be limited by the absence of a shoot meristem (Aberlenc-Bertossi et al., 1999). The similar histological condition is observed in $A$. aculeata somatic embryos, where the shoot meristem is present, but there are fewer leaf primordia. The adition of 6-benzyladenine during development of E. guineensis somatic embryos was found to induce apex differentiation and increase germination rates (Aberlenc-Bertossi et al.; 1999). Other growth regulators, as abscisic acid, are probably related with seed and somatic embryo germination after desiccation and rehydration (Barbedo and Bilia, 1998).

In summary, the seed of $A$. aculeata shows characteristics very similar to the seeds of other palm species, with exception from the invaginations of the distal region of the cotyledon. The somatic embryo differs from zygotic embryo by presenting a lower degree of differentiation of tissues and shoot meristem, and absence of protein and lipids as storage compounds, which is typical of somatic embryogenesis in some species of palms. Anatomical and ultrastructural knowledge concerning the seed and the zygotic and somatic embryos of $A$. aculeata provide important information for improving the seed germination and somatic embryogenesis pro- 
cess for this crop. Thus, it would be necessary to clarify anatomical and ultrastructural changes and enzyme activities during the seed germination.

\section{Acknowledgements}

This study was supported by the Conselho Nacional de Desenvolvimento Científico e Tecnológico (CNPq) and the Fundação de Amparo à Pesquisa do Estado de Minas Gerais (FAPEMIG).

\section{References}

Aberlenc-Bertossi, F.; Chabrillange, N.; Duval, Y.; Tregear, J. 2008. Contrasting globulin and cysteine proteinase gene expression patterns reveal fundamental developmental differences between zygotic and somatic embryos of oil palm. Tree Physiology 28: 1157-1167.

Aberlenc-Bertossi, F.; Noirot, M.; Duval, Y. 1999. BA enhances the germination of oil palm somatic embryos derived from embryogenic suspension cultures. Plant Cell, Tissue and Organ Culture 56: 53-57.

Aguiar, M.O.; Mendonça, M.S. 2003. Morphoanatomy of the Euterpe precatoria Mart. (Palmae) seed. Revista Brasileira de Sementes 25: $37-42$ (in Portuguese, with abstract in English).

Alang, Z.C.; Moir, G.F.J.; Jones, L.H. 1988. Composition, degradation and utilization of endosperm during germination in the oil palm (Elaeis guineensis Jacq.) Annals of Botany 61: 261268.

Barbedo, C.J.; Bilia; D.A.C. 1998. Evolution of research on recalcitrant seeds. Scientia Agricola, 55: 121-125.

Bewley, J.D.; Black, M. 1983. Physiology and Biochemistry of Seeds in relation to Germination. Springer-Verlag, New York, NY, USA.

Buckeridge, M.S.; Santos, H.P.; Tiné, M.A.S. 2000. Mobilization of storage cell wall polysaccharides in seeds. Plant Physiology and Biochemistry 38: 141-156.

Cain, A.J. 1947. The use of Nile Blue in the examination of lipids. Quarterly Journal of Microscopical Science 88: 111-116.

DeMason, D.; Thomson, W.W. 1981. Structure and ultrastructure of the cotyledon of date palm (Phoenix dactylifera L.). Botanical Gazette142: 320-328.

DeMason, D.A. 1986. Endosperm, structure and storage reserve histochemistry in the palm Washingtonia filifera. American Journal of Botany 73: 1332-1340.

DeMason, D.A. 1988. Embryo structure and storage reserve histochemistry in the palm Washingtonia filifera. American Journal of Botany 75: 330-337.

DeMason, D.A.; Sexton, R.; Grant Reid, J.S. 1983. Structure, composition and physiological state of the endosperm of Phoenix dactylifera L. Annals of Botany 52: 71-80.

Duval, Y.; Engelmann, F.; Durand-Gasselin, T. 1995. Somatic embryogenesis in oil palm (Elaeis guineensis Jacq.). p. 335-352. In: Bajaj, Y.P.S., eds. Biotechnology in agriculture and forestry 30: somatic embryogenesis and synthetic seed. Springer-Verlag, Berlin, Germany.

Eeuwens, C.J. 1978. Mineral requeriment for growth and callus initiation of tissue explants excised from mature coconut palms (Cocos nucifera) and cultured in vitro. Physiologia Plantarum 36: 23-28.

Feder, N.; O’Brien, T.P. 1968. Plant microthecnique: some principles and new methods. American Journal of Botany 55: 123-142.

Ferreira, A.G.; Borguetti, F. 2004. Seed Germination. Artmed, Porto Alegre, RS, Brazil. (in Portuguese).

Fki, L.; Masmoudi, R.; Drira, N.; Rival, A. 2003. An optimised protocol for plant regeneration from embryogenic suspension cultures of date palm, Phoenix dactylifera L., cv. Deglet Nour. Plant Cell Report 21: 517-524.
Ganter, P.; Jollés, G. 1969. Common and pathological histochemistry. Gauthier-Villars, Paris, France. (in French).

Hiane, P.A.; Ramos-Filho, M.M.R.; Ramos, M.I.L.; Macedo, M.L.R. 2005. Pulp and seed oil of bocaiúva, Acrocomia aculeata (Jacq.) Lodd. Characterization and composition of fat acids. Brazilian Journal of Food Technology 8: 256-259. (in Portuguese, with abstract in English).

Hughes, J.; McCully, M.E. 1975. The use of an optical brightener in the study of plant structure. Stain Technology 50: 319-329.

Johansen, D.A. 1940. Plant Microtechnique. McGraw-Hill, New York, NY, USA.

Kanchanapoom, K.; Domyoas, P. 1999. The origin and development of embryoids in oil palm (Elaeis guineensis Jacq) embryo culture. Science Asia 25: 195-202.

Karkonen, A. 2000. Anatomical study of zygotic and somatic embryos of Tilia cordata. Plant Cell Tissue and Organ Culture 61: 205-214.

Lott, J.N.A. 1981. Protein body in seeds. Nordic Journal of Botany 1: 421-432.

Meier, H. 1958. On the structure of cell walls and cell wall mannans from ivory nuts and from dates. Biochimica et Biophysica Acta 28: 229-240.

Meier, H.; Reid, J.S.G. 1982. Reserve polysaccharides other than starch in higher plants. p. 418-471. In: Loewus, F.A.; Tanner, W., eds. Encyclopedia of Plant Physiology, New Series 13A, Plant Carbohydrates I. Springer-Verlag, Berlin, Germany.

Moura, E.F.; Motoike, S.Y.; Ventrella, M.C.; Sá Júnior, A.Q.; Carvalho, M. 2009. Somatic embryogenesis in macaw palm (Acrocomia aculeata) from zygotic embryos. Scientia Horticulturae 119: 447-454.

Moura, E.F.; Ventrella, M.C.; Motoike, S.Y.; Sá Júnior, A.Q.; Carvalho, M.; Manfio, C.E. 2008. Histological study of somatic embryogenesis induction on zygotic embryos of macaw palm (Acrocomia aculeata (Jacq.) Lodd. ex Martius). Plant Cell, Tissue and Organ Culture 95: 175-184.

O’Brien, T.P.; Feder, N.; McCully, M.E. 1964. Polychromatic staining of plant cell walls by toluidine blue O. Protoplasma 59: 368-373.

Otegui, M.; Lima, C.; Maldonado, S.; Lederkremer, R.M. 1998. Histological and chemical characterization of Myrsine laetevirens seed. International Journal of Plant Sciences 159: 762-772.

Pammenter, N.W.; Berjak, P. 1999. A review of recalcitrant seed physiology in relation to desiccation-tolerance mechanisms. Seed Science Research 9: 13-37.

Panza, V.; Láinez, V.; Maldonado, S. 2004. Seed structure and histochemistry in the palm Euterpe edulis. Botanical Journal of the Linnean Society 145: 445-453.

Rajesh, M.K.; Radha, E.; Karun, A.; Parthasarathy, V.A. 2003. Plant regeneration from embryo-derived callus of oil palm: the effect of exogenous polyamines. Plant Cell, Tissue and Organ Culture 75: 41-47.

Roth, I. 1977. Fruits of Angiosperms. Gebrüder Borntraeger, Berlin, Germany.

Sané, D.; Aberlenc-Bertossi, F.; Gassama-Dia, Y.K.; Sagna, M.; Trouslot, M.F.; Duval, Y.; Borgel, A. 2006. Histocytological analysis of callogenesis and somatic embryogenesis from cell suspensions of date palm (Phoenix dactylifera). Annals of Botany 98: 301-308.

Schwendiman, J.; Pannetier, C.; Michaux-Ferriere, N. 1988. Histology of somatic embryogenesis from leaf explants of the oil palm Elaeis guineensis. Annals of Botany 62: 43-52.

Sekhar, K.N.; DeMason, D.A. 1988. Quantitative ultrastructure and protein composition of date palm (Phoenix dactylifera) seeds: a comparative study of endosperm vs. embryo. American Journal of Botany 75: 323-329.

Sghaier, B.; Bahloul, M.; Bouzid, R.G.; Drira, N. 2008. Development of zygotic and somatic embryos of Phoenix dactylifera L. cv. Deglet Nour: comparative study. Scientia Horticulturae 116: 169-175. 
Steinmacher, D.A.; Cangahuala-Inocente, G.C.; Clement, D.R.; Guerra, M.P. 2007. Somatic embryogenesis from peach palm zygotic embryos. In vitro cellular \& developmental biology. Plant 43: 124-132.

Tisserat, B.; DeMason, D.A. 1980. A histological study of development of adventive embryos in organ cultures of Phoenix dactylifera L. Annals of Botany 46: 465-472.

Tomlinson, P.B. 1960. Essays on the morphology of palms. I. Germination and the seedling. Principes 4: 56-61.

Ueda, K.; Yoshida, S. 1976. Cell wall development of Micrasterias americana, especially in isotonic and hypertonic solutions. Journal of Cell Science 21: 617.

Verdeil, J.L.; Hocher, V.; Huet, C.; Grosdemange, F.; Escoute, J.; Michaux-Ferriere, N.; Nicole, M. 2001. Ultrastructural changes in coconut calli associated with the acquisition of embryogenic competence. Annals of Botany 88: 9-18.
Verdeil, J.L.; Huet, C.; Grosdemange, F.; Buffard-Morel, J. 1994. Plant regeneration from cultured immature inflorescences of coconut (Cocos nucifera L.): evidence for somatic embryogenesis. Plant Cell Reports 13: 218-221.

Verdeil, J.L.; Hocher, V. 2002. Digestion and absorption of food in plants: a plant stomach. Trends in Plant Science 7: 280-281.

Vidal, B.C. 1977. Acid glycosaminoglycans and endochondral ossification: microespectrophotometric evaluation and macromolecular orientation. Cellular and Molecular Biology 22: $45-64$.

Received May 29, 2009

Accepted March 31, 2010 